\title{
THE BULGARIAN-MACEDONIAN POET, JOURNALIST AND TRANSLATOR, RAYKO ZHINZIFOV ${ }^{1}$
}

\section{Abstract:}

The article highlights the life of the famous poet, translator, writer and publicist R. Zhinzifov (1839-77), whose work belongs equally to the cultural heritage of two modern states: Bulgaria and North Macedonia. The article draws attention to the relationship between Zhinzifov and members of the Moscow Slavic Charity Committee, P.I. Bartenev and I.S. Aksakov, reveals the reasons why Zhinzifov did not return to his homeland in the Ottoman Empire after studying at Moscow University, notes his contribution to the creation of literature during the period of the Bulgarian national revival and his contribution to the education of the Bulgarian people.

\section{Keywords:}

R. Zhinzifov, D. Miladinov, Slavic Charity Committee, P.I. Bartenev, Chertkov Library, I.S. Aksakov, «Bulgarian squad».

АННОТАЦИЯ: М.М. ФРОЛОВА. «БОЛГАРСКО-МАКЕДОНСКИЙ ПОЭТ, ЖУРНАЛИСТ И ПЕРЕВОДЧИК РАЙкО ЖИНЗИФОВ».

В статье освещается жизненный путь известного поэта, переводчика, писателя, публициста Р. Жинзифова (1839-77), творчество которого в равной степени принадлежит культурному и духовному наследию двух современных государств Болгарии и Северной Македонии ${ }^{2}$. Обращается внимание на взаимоотношения Жинзифова с членами Московского Славянского благотворительного комитета П.И. Бартеневым и И.С. Аксаковым, раскрываются причины, из-за которых Жинзифов не вернулся после учебы в Московском университете на родину в Османскую империю, отмечается его вклад в создание литературы периода национального Возрождения и деятельность на поприще просвещения болгарского народа.

\section{Ключевые слова:}

Р. Жинзифов, Д. Миладинов, Славянский благотворительный комитет, П.И. Бартенев, Чертковская библиотека, И.С. Аксаков, «Болгарская дружина».

R ayko Zhinzifov (1839-77) was a poet, translator, writer, journalist. He was born in Veles (Northern Macedonia), into the family of a teacher, I. Zhinzif (Dzindzifi), who, being an admirer of Hellenic culture, called his son by the Greek name Xenophont and gave him an education in Greek at a Greek school. In 1855 the young man began working as a junior teacher at a school

1 The work was carried out with the financial support of the RFBR (grant № 18-512-76004).

2 According to Bulgarian prof. A. Miltenova, the Bulgarian-Macedonian multidisciplinary conciliation commission, which started its work in May 2018, came to an agreement that R. Zhinzifov had a Bulgarian identity. (Editor's note) 
in Prilep, where the senior teacher was the "ardent defender of the Slavs" and enlightener D. Miladinov (c. 1810-62). It was he who turned his gifted ward away from Hellenophilism, revealing the beauty of Bulgarian songs and attracted him to their collection. It was Miladinov who began to call Xenophont by the Bulgarian name Rayko.

At the end of 1857 Miladinov sent his young colleague to teach in the city of Kukush, populated, according to Zhinzifov, exclusively by Bulgarians. The new teacher introduced the Bulgarian language and literacy into the school curriculum. Both boys and adults began to come to him to learn their native language, and "even priests, for in the churches it was necessary to replace worship in Greek with Slavic.'

In July of the following year, Zhinzi-

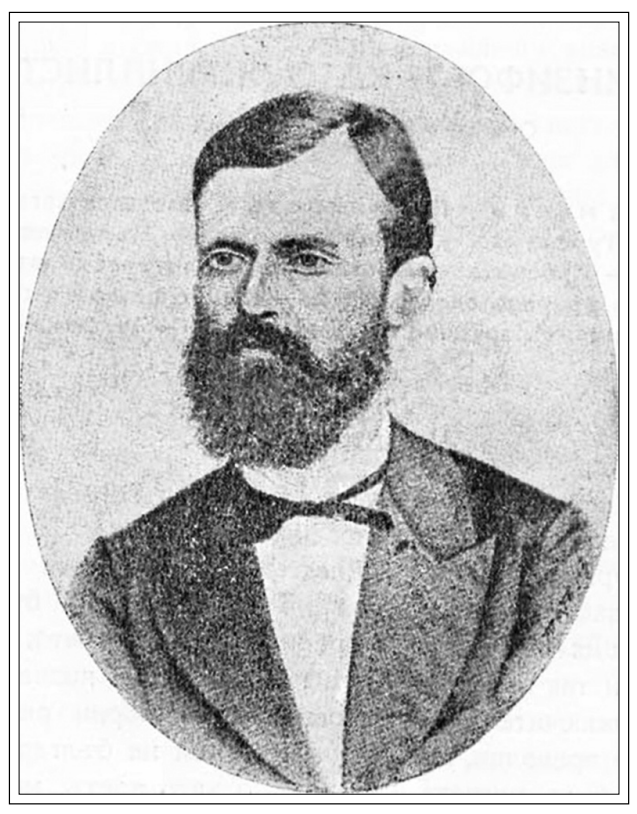

Aportrait of Rayko Zhinzifov fov arrived in Odessa as one of a cohort of eight Bulgarian-Macedonians whom Miladinov sent to study in Russia with the assistance of Russian public figure A.V. Rachinsky (in 1861-62 he was the Russian consul in Varna). Here he met with G.S. Rakovsky (1821-67), a well-known Bulgarian herald of freedom from the Turkish yoke. He made such an impression on the young man that Xenophont finally decided to change his Greek name to the Bulgarian Rayko. It's true that official papers his publications in Russian newspapers and letters to Russian addressees were still not signed as Rayko, but as Xenophont. In Moscow they addressed him as Xenofont Ivanovich. However, for the Bulgarians he was Rayko.

At the end of this year, Zhinzifov arrived in Moscow and became a scholarship holder of the Slavic Charity Committee, and the next year he entered the Faculty of History and Philology of Moscow University. But the scholarship of 20,000 rubles in silver was not enough, since the Bulgarian student had large expenses because of the Russian cold climate. Rayko's father did not respond to his requests for money. Effective help came from the members of the Slavic Committee, who, knowing of the financial needs of their students, helped them to find additional income. Thus in 1862, P.I. Bartenev (1829-1912), a member of the commission in charge of the affairs of Bulgarian students, invited Zhinzifov to work in the Chertkov library in the summer during his absence. Bartenev was then the head of this library, which, in memory of its collector, historian and bibliographer, A.D. Chertkov (1789-1858), his son G.A. Chertkov decided to open to the public as the first free private library in Moscow. This took place in 1863. 
Xenophont coped well with his duties, and Bartenev invited him to take the post of assistant librarian in the Chertkov library with a salary of 20 rubles per month. However, his studies kept him too busy to allow him to accept this offer. In October 1862 Bartenev recommended Zhinzifov as a teacher to the family of a certain Waldgard, then Baranov (in the summer of 1863), and A.N. Karamzin (in 1865).

In Bartenev's house, Zhinzifov was received "not as a friend, but as a close relative." A cordial relationship was established with him and with the family of I.S. Aksakov. From letters to Bartenev, it is clear that Zhinzifov loved music, painting, theater; he periodically visited "places of amusement, that is, to different Hermitages with Saxons, singers, dwarfs and so on and so forth."

During his studies, Zhinzifov earned extra money at the weekly newspaper of I.S. Aksakov, Den' ("The Day"). His first journalistic articles ("A letter from one of the Bulgarian students in Moscow to the editor," "A few words of a Bulgarian about the feud between the Greeks and Bulgarians," "Dmitry and Constantine Miladinov," etc.) attracted attention due to the author's undoubted literary talent and his ardent heart of a patriot.

His studies at the university and worries about the next meal could not distract Zhinzifov from his sadness about the plight of the Bulgarians in the Ottoman Empire and the lack of their own literature. In the early 1860s, many natives of the Ottoman Empire studying in Moscow later made a significant contribution to the national and cultural revival of Bulgaria: M. Drinov, G. Theokharov, S. Filaretov, L. Karavelov and many others. They formed the "Bulgarian squad," one of the goals of which was to promote the development of Bulgarian literature. Zhinzifov's first literary experiments appeared precisely on the pages of the Bratsky trud ("The Brotherly Work") magazine published by the squad.

In addition, he published the collection Novobalgarska Sbirka ("New Bulgarian collection," 1863), which included his translations of poems The song on Igor's Campaign and Kraledvorsky Manuscript by T. Shevchenko into Bulgarian, and several of his own

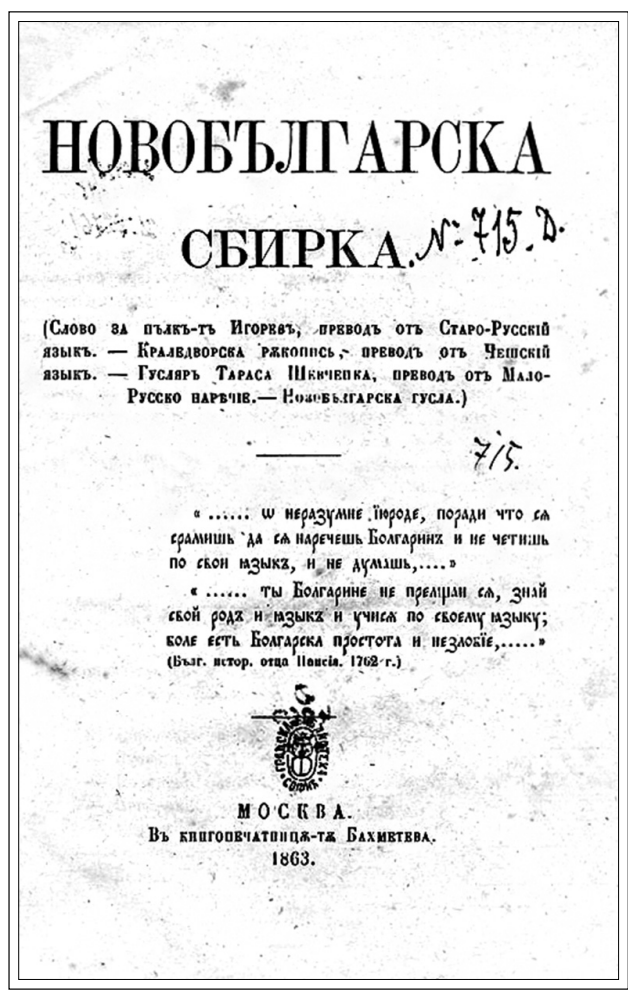

The title page of the collection "Novobalgarska Sbirka".

Moscow, 1863 
works. As an epigraph, Zhinzifov took the famous words of Paisius of Hilendar, urging his compatriots not to be ashamed to be called Bulgarians and to study, read and think in their own language. It should be emphasized that Zhinzifov had become familiar with the History Slavo-Bulgarian by Paisius of Hilendar in the Chertkov library, where a copy was kept, made specially for A.D. Chertkov in 1844 from the Zheravna manuscript. The author of the book, Novobalgarska Sbirka, published it in the 100th edition, intended to distribute the book free of charge to the Bulgarian schools in the Ottoman Empire and to award it to the best students.

In 1864 Zhinzifov graduated from Moscow University with a candidate degree. He received invitations from Belgrade, Sofia, Bolgrad and other cities to take the post of a teacher. The modern Bulgarian scholar I. Konev explained his refusal to go to the Balkans as "fear" of joining the revolutionary forces of Bulgaria in the 1870 s and "working to liberate his people in the extremely difficult conditions of Turkey." It was precisely in the contradiction between his love of his motherland and his "flight" from the revolutionary movement, from direct participation in the political life of Bulgaria, that Konev saw the tragedy of the fate of Zhinzifov, who preferred to act in the name of liberating his people with his pen. The Bulgarian scholar D. Lekov believed that the difficult mission of an "awakener" was simply beyond Zhinzifov's power.

Bulgarian scholars did not know of Zhinzifov's letter dated 11 November 1865 , which is stored in the archival fund of diplomat M.A. Khitrovo, who then served in the Russian mission in Constantinople. It turns out that Zhinzifov had accepted Russian citizenship and was looking for a teaching position in the Bulgarian school of Constantinople, but there were no vacancies.

He was accepted as a teacher of Greek at the Lazarev Institute of Oriental Languages in Moscow and simultaneously worked as a teacher of Greek at the 1st and 2nd Moscow gymnasiums. At the same time, his friend Nesho Bonchev, who went down in history as the first Bulgarian literary critic, reported that Zhinzifov "received a very good salary." In the 1870s Zhinzifov taught at the Lyceum of Tsarevich Nikolay, at the 5th Moscow gymnasium. In 1875 he became a collegiate assessor of the 8th rank, which corresponded to the rank of major and gave him the right to personal nobility.

In 1866 Zhinzifov made a trip to Bulgaria and Macedonia, but could not reconcile himself with the Turkish rule there and returned to Moscow. After that he wrote an extensive essay saturated with many facts, "From the Notes of a Traveler in Macedonia," published in the same year in five issues of the "Modern Chronicle" newspaper.

In February 1868 Zhinzifov became a member of the Moscow Slavic Committee and a member of the Imperial Society of Lovers of Natural History, Anthropology and Ethnography. Two years later he was elected a full member of the Bulgarian Literary Society, which was a prototype of the Bulgarian Academy of Sciences. 
Communicating closely with members of the Slavic Committee and prominent Slavophiles, Zhinzifov could not help but share their views. It is quite clear that such people as bright, talented, and sincerely soul-sick for the Slavic cause I.S. Aksakov and N.A. Popov had a tremendous influence on the young man who came from a remote corner of the Ottoman Empire then Eyalet of Rumelia (or of Bitola). Their active role in the enlightenment of the Slavic peoples, including the Bulgarians, was consonant with Zhinzifov's thoughts, feelings and subsequent activities along this path. He published in lot of Russian periodicals ("The Day," "The Contemporary Chronicle," "Moscow," Moskovskiye Vedomosti, etc.), informing the Russian reader about the events taking place among the Western and Southern Slavs.

Zhinzifov worked a lot and fruitfully in the name of enlightening the Bulgarian people. On 26 June 1864 he wrote to Bartenev that his first duty was to publish his or someone else's books to help create Bulgarian "literature," the absence of which simply "drove him crazy." Zhinzifov made Bulgarian translations of poems by T.G. Shevchenko, M.Yu. Lermontov and other poets, as well as several of his own original works, for example, the poem "Bloody Shirt." It contained the story of an old Bulgarian woman about the Turks' murder of her only son for no reason. His bloodstained shirt, kept by the unhappy mother, appealed for vengeance, and these feelings resonated with the Bulgarian reader. Zhinzifov sent his translations and works in Bulgarian to the Bulgarian periodicals: "The Bulgarian Bee," "The Danube Dawn," "Nationality," "Macedonia," "Freedom," etc. He became the first historian of Bulgarian literature, write a special article for the collection "Poetry of the Slavs" in which the development of Bulgarian literature was traced, starting with Paisius of Hilendar up to 1871.

Zhinzifov's literary work belongs equally to two states at once: Bulgaria and North Macedonia. Until 1878 their lands were part of the Ottoman Empire, and in its Orthodox "millet" which united all the Orthodox peoples of Turkey, there was an intensive demarcation of Greeks, Hellenophiles, adherents of the Patriarchate of Constantinople, and Slavs: Bulgarians, who defended the right to their own church independent of Greek Ecumenical Patriarch. In 1870, in accordance with the sultan's firman, the creation of the Bulgarian Exarchate was announced, and a competition for congregation began with renewed vigor in the provinces with a mixed population (primarily in Macedonia): to which church would people go as a result of a public poll. In his writings, Zhinzifov reflected the ups and downs of church feuds between Greeks and Bulgarians, while protecting the interests of the Slavs who lived on the territory of the modern states of Bulgaria and North Macedonia, whom he called Bulgarians. In addition, it was important for him to prove to the whole world that in his native Macedonia, there lived not Greeks, but Slavs-Bulgarians (Bulgarian-Macedonians). At that time, there was no concept of a separate Slavic people: the Macedonians; Zhinzifov did not live to see this era. 
On the eve of the Russo-Turkish war of 1877-78, Zhinzifov began to compose "Road builder in Macedonia, or otherwise a geographical and statistical description of Macedonia" as well as a small Russian-Bulgarian dictionary. However, he did not have time to complete his work on this: death came to him on his birthday on 15 February 1877, when he was 38 years old.

In Russia, which became Zhinzifov's second homeland, his talent as a poet, translator, writer and journalist was revealed. His works in Bulgarian addressed to the Bulgarian reader contributed to the development of the Bulgarian revival and enlightenment. He fulfilled another, very important mission facing Bulgarian patriots: the creation in Russian society of the image of an oppressed, suffering Bulgarian people, waiting for help from Russia to both resolve the church issue and to assist in liberation from the Turkish yoke.

Translated by Igor Kaliganov

\section{BIBLIOGRAPHY}

Bershadskaya M.L. "Rajko Zhinzifov i slavyanofily." In: Makedonskij yazyk, literatura i kul'tura v slavyanskom i balkanskom kontekste, Moscow, 1999. S. 231-36.

Konev I. "Rajko Zhinzifov." Izvestiya na Instituta za balgarskata literatura. Kn. VII. Sofia, 1958. S. 151-91.

Lekov D. "Rajko Zhinzifov. Literaturno-kriticheski ocherk." Sofia, 1979. 87 p.

Penev B. Istoriya na novata balgarskata literatura. T. 3. Sofia: Balgarski pisatel, 1977. $678 \mathrm{p}$.

Smolyaninova M.G. "Rajko Zhinzifov v Rossii." In: Makedoniya: problemy istorii i kul'tury. Moscow, 1999. S. 100-22.

\section{ILLUSTRATIONS}

1. A portrait of R. Zhinzifov.

2. A portrait of R. Zhinzifov.

3. A portrait of R. Zhinzifov, 1864.

4. A portrait of Dimitar Miladinov.

5. A portrait of P.I. Bartenev.

6. A portrait of I.S. Aksakov. Artist I.E. Repin. Oil. 1878.

7. The title page of the collection "Brotherly Work," Issue IV, Moscow, 1862. 